\title{
Autonomy and Financial Viability of Local Authorities in the Limpopo Province Republic of
} South Africa

\author{
Gezani Mazibuko \\ Director First choice achievers learning centre NPO \\ hlohlo@lantic.net
}

\begin{abstract}
Premised on the state's capacity to govern ultimately derives from capacity to manage the budgetary process, this study relates to the autonomy and viability of municipalities in Limpopo Province. The autonomy and financial viability of the Limpopo Province local authorities poses a challenge to the provincial as well as national government. The purpose of the research was to examine whether local authorities in this Limpopo province are autonomous. In addition to determine if they are financially viable. A descriptive research was used to for this research. Based on the outcome of the study, the researched local authorities are not financial viable and autonomous as they depend on grants from national government.
\end{abstract}

Keywords: Autonomy, financial viability, tax base, local authorities, semi-urban, rural.

\section{Introduction}

The autonomy and viability of local authorities had been a big problem for the South African government in the past. During the apartheid era targeted commissions and committees of enquiries investigated the autonomy and viability of these institutions. It is apparent that the new government has inherited the institutions, which are not viable, with service backlogs, limited financial resources and insufficient physical capacity.

According to the Ministry for the Provincial Affairs and Constitutional Development (South Africa, Republic, 1999a) there was financial instability in various municipalities in South Africa in the past. This state of affairs was exacerbated by the insufficient tax base, service delivery back logs, deteriorating infrastructure and credit worthiness. In addition borrowing capacity, administrative inefficiencies, in taxes and other riddles were also thorny issues. Some of the issues prevalent to South African municipalities then were articulated as lack of capacity in terms of giving cost effective budgeting, accounting systems, financial reporting. Certainly management practices were weakened, revenue which could only be generated by the advantaged white municipalities with small populations to serve. In addition, , those municipalities had economic resources to tax. To this end, the financial shortfall was built into local municipalities for black areas. A case in point as Humphries (1992) posits is that Croeser's analysis of local authority finance in which he argues that white local authorities have more spare financial capacity that they admit to, and could therefore shoulder the burdens of a single tax base with the townships, would seem to be designed to limit claims by local authorities on central state for additional finance. The above arrangement led to discrimination and segregation in rural areas. These fundamental paradigms contributed too many boycotts during the year prior to 1994 in black communities. Community bodies and other organized civil society started to organize to fight and crying inadequate service delivery rural areas. They organized boycotts against rents and service charges and consumer activities. The contention and fight was to achieve a common tax base for one city or town.

South African government made various investigations in the past. The motivating factor is that a local authority requires money to perform its functions and provision of services (Cloete, 1993a; Craythorne, 1997). In the light hereof the study describes and analyzes the need that should serve as principles in local authorities' financial viability. Those who are in authority will realize the need for efficiency and effectiveness as well as on responsibility and public accountability for collecting of municipal revenue. The citizens in all the municipalities will realize the need to participate in meetings of matters concerning the derivation of revenue of their areas through ratepayers' association and other interest groups where necessary. The municipal ratepayers can also participate indirectly in the municipal decision making processes on taxation and other revenue collected from them. The study on autonomy and financial viability will seek to provide the basis to evaluate the conduct of councilors. To this end, the municipalities will realize that they need some kind of autonomy to exploit more revenue for their areas of jurisdiction. 
This study on autonomy and financial viability will create more ways for others to explore on the subject especially in determining the affordable sources of revenue for the local authorities that can enhance their chances to gain more autonomy. This will also be an opportunity for the local council to develop the property tax base and other tariff in the rural municipalities that will stimulate a lot of research, more interrogation by those who are interested in finding the way of getting sufficient tax base and revenue sources for the municipalities. The autonomy and financial viability of the local authority is a new phenomenon in the rural municipalities and especially to the majority of African people. The study therefore seeks to examine the autonomy and financial viability of the local authorities in the Limpopo Province. HO: It is apparent that these local municipalities do not have autonomy with regards to the various decisions in their municipal areas. Apparently various municipalities still receive instructions on how to handle the day to day business from provincial and national governments. H1: It is apparent that these local authorities do not have sufficient tax base in order for them to be financial viable. It seems that these municipalities still receive subsidy from the national and provincial governments to finance their day to day activities and even capital projects.

Conceptualization autonomy: The conceptualization framework will finds it expression on the functions of a local municipality, history of municipalities in South Africa, White Municipalities, Interim phase of local government after 1994 and Municipalities after 1999, institutional autonomy and financial viability. These issues will above all underpin the conceptualization framework.

Functions of a local municipality: - The broad developmental goals of local government have been clearly stated out in Legislation and acts of parliament (South Africa, Republic, 1996) (South Africa, Republic, 1998b). In order for the municipality to function properly, there must be a tax base required for the municipality. A primary source of revenue base comprises of rates and service charges paid by residents and businesses. Councils are therefore mandated to collect rates and levy service charges. These processes comprise a significant administrative function in and of themselves. Municipalities can potentially provide a very wide range of services, dependent upon their size, local and financial standing. Municipalities need money to pay services and the necessary activities. The constitution has brought with it the new set up in the history of the South African municipalities (Cloete, 1995; Gildenhuys, 1997a) and mandated local government in terms of legislation with functions which every citizen is supposed to enjoy. The words of the Executive Mayor of Johannesburg city, Mr Amos Masondo regarding local government are encouraging. He said that in Gaffney's (2001): “Councils who thinks community and use resources in the interest of communities will see the results of their efforts in the local economy. There can be no other national for our existence than to service our communities and ensure we deliver quality service".

History of Local Government in South Africa: The history of South African Local Government was characterized by one South Africa with two South African perspective: one White South African municipality and one Black township scenario which was also complex in the sense that it is also had semi urban/rural areas and also tribal areas which in one way or another fragmented. The white municipalities were the only municipalities that were well equipped in terms of infrastructure. The Black Townships were some kind of simulation of white municipalities because they were simulating what the white municipalities had. The white-apartheid South African municipalities were born out of the following acts of parliament: The Union of South Africa, South Africa Act, 1909 (South Africa, Republic, 1909), Republic of South Africa Constitution Act, Act 32 of 1961 (South Africa, 1961a) and the Provincial Government Act, Act 32 of 1961(South Africa, Republic, 1961b). The Provincial Act conferred powers on provincial councils to, legislate on municipal institutions, divisional councils and similar institutions. The legislations passed since 1910 resulted in the establishment of municipalities in the four apartheid provinces. It also extended to the divisional councils in the Cape Province, village councils and village management boards and town boards, health committees and local boards (Craythorne, 1997). Those days local government reference was made only to white municipalities nothing else.

White South African Municipalities: Since unification in 1910 the viability of South African local governments has been a governmental problem. The problem has focused mainly on financial matters. The RSA's concern about the financial welfare of local government has been borne out of its appointment for years of approximately 10 commissions of enquiry into the financial affairs of municipalities. The commissions in questions are Murray Commissions in1910 up to the Browne Committee of 1990(South 
Africa, Republic, 1990) and Croeser working group of 1982(South Africa, Republic, 1982a). Despite all these, the viability of local government remains a problem (UNISA, 1994). Black local authorities were established in terms of the Black local Authorities Act of 1982(South Africa, Republic, 1982b). Until less than a decade ago, references to local government in South Africa implied white local government. It had always been the intention of the government that Blacks, Coloureds and Indians would receive some form of local government when they were able to govern themselves (Hanekom, et al, 1987). The development of local government for Black, Coloureds and Indians, gained momentum after the constitution was proposed to the central government (Cloete, 1997). These local governments did not have proper infrastructure to warrant them local government status, which a community can be proud to have. A community can be seen, being, economic and ability to maintain itself. A community, its structures and the way of life it generates, its place in relation to other communities, is unique and has certain characteristics that it does not share with other communities. A community should be provided with social infrastructure which it can be proud of (Meiring and De Villiers 1994a; Meiring and Parson, 1994b) rural communities reside in underdeveloped areas, far from work opportunities, unsustainable rural settlement and lightly unequal access to services and amenities. There was also Bantustans which had a system of township municipalities, which were established in terms of proclamation R293/1962 (South Africa, Republic, 1962), which also were some monsters to please black Bantustan leaders.

Interim phase of local government after 1994: This era was the first round of restructuring, arranged in terms of legislation "Local Government Transitional Act, Act 209 of 1993 (South Africa, 1993). The legislation was throughout dealing with this practical way of making the transition from essentially "white only" municipalities for all people (Cloete, 1995). The act brought with it coexisted a time, with homogenous councils.. The establishment of District councils, Representative councils and rural councils were extended to the rural areas. In terms of the above act, 843 Transitional local councils were created.

Municipalities after 1999: The RSA provides reorganization both administrative and political set up. The Municipal structures Act was passed as new, Act 117 of 1998(South Africa, Republic, 1998a). It was geared to c0incide with the second round of municipal elections. The Act provided and included remote areas, i.e. the wall-to-wall local government. The Act gave birth to three forms of municipalities namely; Category A that are metropolitan councils, Category B which are local municipalities or areas and Category C which are District municipalities. The Category B and C municipalities with subtle two hundred and eight four (284) municipalities in Republic is a key part of building viable, developmental local government systems within the framework of cooperative governance.

Institutional autonomy: A municipality has the right to govern, on its own initiative, the local government affairs of its community, sub rent to national and provincial legislation (South African, Republic, 1996). In addition, the national or a provincial government may not compromise or impede a municipality's ability or might to exercise its powers or perform its functions. The provisions are a guarantee of autonomy, but still subject the municipality to the laws made by national and provincial levels of government. To govern, it means the power to compel citizens to pay taxes or fees and levies and to enact legislation, no matter how sub ordinate and to enforce that legislation directly or indirectly (Craythorne, 1997).

Financial viability: Ismail et al (1997) posit that financial viability is very crucial since it deals with the financial capacity of the local authority to run its program and projects. The viability criteria dominate much analysis because the cost is always of concern to the client and because analysis has excellent tools for comparing criteria expressed in monitory values. According to (Catarese and Snyder 1979), there are four basic questions, which divide the criteria of economic and financial viability: What effect does the proposed policy or program have on the client's fiscal situation? Is it cost effective? That is, is it the least expensive means of adequately and effectively addressing the problem definition? It is economically feasible? Will it maximize the client's return on investment? What additions economic impacts would it have, and how significant are they? For a public client, this might man analyzing the effect of the policy on the local economy. For a private client it might involve forecasting the reactions of competitions. Efficiency is measured in costs per unit of output or benefit and the alternative with the lowest ratio is best. But a very efficient policy does not directly and fully addresses the problem statement, is of little use to policy analyst, unless it makes up 
only one part of large solution. For this reason, the concept of cost effectiveness is generally more useful as a policy analyst criterion.

Profile of Limpopo Province: The Limpopo Province shows that it is the northern provinces which borders Mozambique in the East, Zimbabwe and Botswana in the North and West and is sub-divided by the N1 motorway- that runs from Johannesburg -Zimbabwe. It connects the province to South Africa's largest single market Gauteng and onwards to Durban, the country's busiest port. The Province's titanium and the richest mineral deposits in Southern Africa and one of South Africa's richest agricultural exporters of sub-tropical and citrus fruits. Manufacturing is the province's least developed industry.

Limitations of the study: The study which was conducted in 1999 to 2002 did not try to do an all-embracing analysis of the autonomy and financial viability of the local authorities in the province. The study on autonomy and financial viability of local municipalities is considered as vital factors for self-sustenance of municipalities. The study is centered on the confidentiality and sensitivity of the nature of data. The study was limited by some municipalities which did not, respond to the questionnaire developed and sent to them.

\section{Literature Review}

The government appointed approximately 10 commissions of inquiries to determine the viability of financial affairs of local authorities.. The commissions in question are amongst others, the Murray commissions in 1911 up to the Browne Committee of 1980 and the Croeser Working group of 1982. Despite all these, the viability of local government remains the problem (UNISA, 1994). A similar study was conducted by the University of South Africa about the reality check of four authorities in the Limpopo. the report indicated that the financial status varies according to the size, historic development and structure of the local authority (UNISA, 1999). The literature review will focus on financial autonomy, sources of revenue, loans and capital finances, property taxes, services charges, finances by means of subsidies and utilization of financial resources. In addition, institutional systems, the role of district and local municipalities, own revenue, financing municipalities in rural areas and municipal borrowing will enhance the discussion.

Autonomy: The role of local government was best articulated by the former president Nelson Rolihlahla Mandela (SALGA, 2001) when he said : "Local government in the past has traditionally been the local face of apartheid, immersed into practices of upholding influx control and residential segregation. These were the foundations of residential apartheid and forced removals. The arrival of democracy marked the dawn of a new era of constitutionalism in which the Bill of rights will play a pivotal part in the development of our democracy. It binds all levels of government in its daily interaction with communities that will bear the responsibility for the human rights culture at local level (where) we will be translating human rights into a living reality." It is therefore no doubt translating the human rights rhetoric into living and concrete reality.

Institutional autonomy: According to (De Villiers, 1992), autonomy refers to the ability of sub national government to act in self-determination in such a way that certain affairs can be conducted and decisions taken without external interference. The concept of autonomy indicates the judicial capability of an entity to act at its own direction. It is however, fortunate or unfortunate that the ability of the entity to act may be influence by a number of factors such as financial resources, managerial skills, and administrative capability and infrastructure constraints. The local authorities will be looked into in conjunction with the financial viability of such authorities. A practical consideration of a local autonomy is to a large extent determined by its ability to finance its activities that are planned. In order to be successful there should be a balance between the constitutional obligations that a local authority has and the economic resources given to it for purposes of fulfilling these obligations. In most cases the local authorities depend on grants from national government to finance its activities. When the assistance becomes precious and serves as a base for informally amending the constitution, the autonomy of the local authority is at stake. It is also imperative to realize that the local authorities are by and large reduced to begging for assistance in order to undertake projects that constitutionally devolved to them but not getting sufficient financial resources (De Villiers, 1992).

It is necessary to acknowledge levying and raising of taxes by national government. Generally speaking the role of the national government as the tax levying machinery is paramount. Certainly, national government is 
in terms of legislation responsible for the collection of most taxes, thereafter they are distributed as required to both provincial and local authorities. An overview of various taxes that collected points to taxes collected by national government for its own activities, taxes collected are shared with authorities, taxes collected by national government and paid finer to the provincial and local authorities and those taxes that are collected by the provincial and local authorities. The role of the national government in this study is emphasized due to the fact that it has the ability to collect taxes nationally. It is important to acknowledge the fact that there are certain taxes that are earmarked in the constitution for provincial and local authorities irrespective of the fact that the centre collects them.

The national government can utilize various methods to assist the provincial and local governments to contribute income that has been collected nationally. National uses equitably share of revenue to distribute revenue to various spheres of government. It therefore gives the national a lot of coverage to influence activities that is planned by provincial and local to render financial assistance on conditions that certain regulations are complied with, despite the fact that a specific manner resides under the competency of either provincial or local authorities. De Villiers (1992), states that these might have an impact to the local authorities by limiting the autonomy of a provincial or local authority. It would not however change the rightful relationships as prescribed in the Constitution.

The question of revenue sharing leaves much to be desired. On the positive note it guarantees the local authorities a minimum income, which can help them in planning. On the negative note, it is inflexible and incapable of adapting as circumstances changes. At the same time it is important that the local authorities must have some autonomous tax base as a guarantee against intervention. In the light hereof, local authorities' autonomy, if viewed negatively, constitute a threat to national unity and can present an obstacle to national integration. If viewed positively it provides a basis for the maintenance of self - identity, giving people the opportunity to express their views and to participate in governmental processes on local, provincial and national levels.

Positive side of autonomy: Autonomy if viewed positively can yield the following aspects: encourage participation, reduces conflict by enabling local authorities to adopt policies that best suit their needs; it provides opportunities of combining benefits of both unity and diversity; tights are granted; encourages domestic participation. In addition it improves communication between the populations; contribute to the more successful management of national economic development; improves the quality of administrative technical and political leadership; contributes to a more effective governmental process; encourages experimentation in problem solving; increases political stability and national unity.

Negative side of autonomy: On the other side, autonomy can lead to an emphasis on regional differences, which threaten national unity; limit the ability of local authority and cannot survive without capacity building. However, the local authorities should be aware to serve as administrative lackeys of national government. If local authorities cannot attain a substantial autonomy by raising a large portion of their own funds it will be difficult for the community to gain trust and confidence. If they are unable to improve the lives and conditions of their communities, they will not only have difficulty in developing into credible sphere of governments, but will also fail to perform one of their most important constitutional functions, namely promoting socio economic development within their areas of jurisdiction (Ismail et al, 1997).

Financial autonomy: Municipal finances are an overriding factor in the management of the local authorities (Ismail et al, 1997). Local authorities need money, to provide public services. The rural areas can also contribute towards the financial autonomy and viability of their municipalities (De Beer and Lourens, 1995). In most instances the population found in the rural areas is more than the town population. Through the development of proper financial strategy and tax bases the categories of teachers, magistrates, nurses and clerks can definitely boost economy in these municipalities. They are potential ratepayers and these have to be exploited drastically. To this end, financial sustainability is characterized by continuity, resiliency and favorability. While financial viability measures what policy or program costs and what benefits it produces in return. The above definition ceteris paribus would in a way determine financial autonomy of municipalities. 
Sources of Income: The district and local municipalities have an important role in ensuring that revenue sources are generated successfully in the various areas. Hereunder the roles of these municipalities and sources of income are discussed:

Roles of district Municipalities: District municipalities have the key role to play in: promoting integrated regional development. Such role recognizes the linkages between urban nodes and surrounding rural areas. In addition, the role of districts should be as a supporting primary tier in rural areas and in particular providing capacity for rapid delivery in areas where rural municipalities lack capacity (Gildenhuys, 1997b; Esman, 1991).

Roles of local Municipalities: Local municipalities are there to determine the choice of a tax rates to be imposed, to define the tax base, to determine the tax rate and to administer about cost of service provision and traditionally the lifeblood activities (Emislie, 1991). Due to shallow tax base, national and provincial governments provide many municipal services in rural areas through subsidies.

Sources of income of municipalities: Local authorities require money to perform its functions. The local authority needs money to engage staff and to buy machinery and materials to render services to the public. In order to spend money, it should first be raised from one source or another. The sources of income of local authorities are prescribed in terms of legislation (Cloete, 1993a). The sources of income of local authorities are analyzed hereunder:

Property rates: Local authorities obtain a considerable portion of their income from rates and levied on fixed property (land and building). Most of the former black and especially rural areas remain outside of the property tax net.

Services charges: represent the largest source of revenue for municipalities. In most instances the municipalities, have to repay the original service providers such as ESKOM and Water boards. The service charges comprise mainly of electricity, water, refuse removal, sanitation and rates and taxes. The local authorities require residents to pay for the services provided by the local authorities, for example payment for sewerage services, entrance fees to swimming baths and parks., rent for municipal halls and other buildings (Cloete, 1993a).

Financing municipalities in rural areas: Municipalities must have mechanisms for financial viability of rural areas. The following are some of the mechanisms: - Sectoral funding for infrastructure, raising loans for capital expenditures, raising of revenue from industries where applicable and the possibility of local government harnessing the flow of revenue in communal land areas. Rural areas exist largely in name with little or no fiscal capacity. They have very limited economic base and the tax base is very restricted mainly because there is no property or land tax or other levies collected in rural areas. Local authorities, impose rates on property and surcharges on fees for services provided by or on behalf of the local authority (Cloete, 1997). A municipality may use the property rating such as: Assessment rates, valuation of property, site rating, flat rating and differentiating rating to add its revenue.

Loans and capital finance: Capital projects can run into costs amounting to millions of rand. It is not possible to finance all the projects at the given point in time. Local authorities raise loans to finance capital expenditure. It is therefore possible for them to use internal sources of financing such as the capital development fund. Another way is to obtain loans from higher levels of government to finance capital expenditures out of income derived from service levies income from the district council levies, of their projects.

Subsidies and equitable shares: Local authorities receive subsidies from provincial and national governments, for example to enable local authorities to provide health service which must be provided to protect the population against diseases (Cloete, 1993c). Specific forms of governmental relations are established when a higher authorities give out money by means of a grant or subsidies (Hattingh, 1998). The aim is to boost the income, which is received by the municipalities. The subsidy that they receive is able to balance their excess between the revenue collected and actual expenditure incurred. Since 1998/99 financial 
year South African municipalities have received allocations from the "equitable share" of national revenue in terms of the constitution (South Africa, Republic, 1999b). The equitable share is based on the notion of equity transparency, predictability and accountability that is linked to the new intergovernmental fiscal system. The government has established grants for service delivery. The objective of these grants is to fill gaps, between funds needed to maintain the basic facilities for the operation of local government. In terms of the requirements, those municipalities with sufficient revenue raising capacity to finance the basic facilities of local government do not receive these grants. To qualify for these grants, the municipalities should have populations not exceeding 2000 people. The municipalities with higher levels of average income receive smaller grants. This is the case because high-income municipalities are considered to have sufficient revenue raising capacity to finance the basic operations of government on their own (South Africa, Republic, 1999c).

Utilization of public finance resources: The effective utilization of Public financial resources involves complicated steps, which affect Capital-Revenue, stores, equipment and building. The following are some of the issues which the Municipal Manager, Town Treasurers and all official who work with public financial resources must consider when dealing with finances. Introduction, monitoring of sensible procedures for the safekeeping and handling of money, stores and equipment, enforcement of financial policing, co-ordination community charges, supervision of correct accountancy practices and documentation or recording of financial transactions (Meiring and De Villiers, 1994a). Public services and development of a community cannot take place without money. The financial requirements of an institution must be taken into account. Maximum satisfaction can only be obtained if the money is as effectively utilized as far as possible.

Roles of councils and officials: The councils and obviously the officials and in particular the Municipal Manager and his top management has an important role to play regarding financial autonomy and viability. The municipal councilors within the municipality's financial and administrative capacity have the right to govern on its own imitative the local government affairs of the local community. In addition, have to exercise executive and legislative authority and finance the affairs of the municipality. Cloete (1997), posits that the council has to pass by laws, approve the budgets, and impose rates and other taxes, levies and duties and raising of loans. The Municipal Manager is responsible and accountable for the formation and development of an economical, effective, efficient and accountable administration (De Viliers and Meiring, 1995). They have to ensure that the system of financial management and internal control are fundamentally established. They have to ensure that financial and other resources of the municipality are utilized effectively, efficiently, economically and transparently. Above all they have to ensure that all revenue due to the municipality is collected.

\section{Research Methodology}

The research was conducted during the years 1999-2002 on the autonomy and financial viability of local authorities in Limpopo Province. The research used qualitative exploratory and descriptive analytic methods. Secondary and primary data was collected from the sample municipalities. They were used because primary source for example offers a written evidence or oral account of information. On the other hand secondary data provides information already available in libraries or archived materials. These are some of the reasons why books, magazines, periodicals, newspapers, articles and interviews were used in this study. Questionnaires were developed to gather information from the sample population. The reason to have opted for the municipalities in the Limpopo Province is because of their uniqueness in terms of the mixture of the urban and rural municipalities' features (CEPAD and Solace International, 1996). Twenty -two municipalities and six district councils were requested to provide information by means of a questionnaire. Only Thirteen municipalities or localities were researched using the above analysis methods.

\section{Results and Discussion}

Arguably, financial viability has to revenue or income exceeding its expenditure during a particular financial year. For the purposes of this study, financial viability is considered to go hand in hand with self-sufficiency or self-reliance. 
The research revealed that, some municipalities were not in the position to answer all the questions as developed and sent to them. Others especially the rural municipalities such as Greater Giyani, Blouberg, Mutale, Thulamela, Bushbuckridge, Makhuduthamaga, Lepelle-Nkumpe and Aganang with the exception of Fetakgomo municipality did not return the questionnaires and partly as a result of the limited time available.

All former white municipalities namely: Makhado, Musina, Modimolle, Lephalale, Greater Tzaneen, Molemole, Polokwane, Mogalakwena, Bela-Bela, Thabazimbi and Ba- Phalaborwa, with the exception of Mookgophong, Greater Letaba and Maruleng municipalities responded to the questionnaire. However, it should be mentioned that 52 percent of local municipalities responded while 48 percent did not respond to the research.

Table 1 outlines the financial viability indicators (Marshall and Douglas, 1997) relating to measures, questions and their key characteristics. Many questions and interpretations are possible and desirable in order to further the understanding of financial viability and thus can be replicated. This was one such municipal viability framework to help built a significant part of this study.

Table 1: Financial Viability Indicators

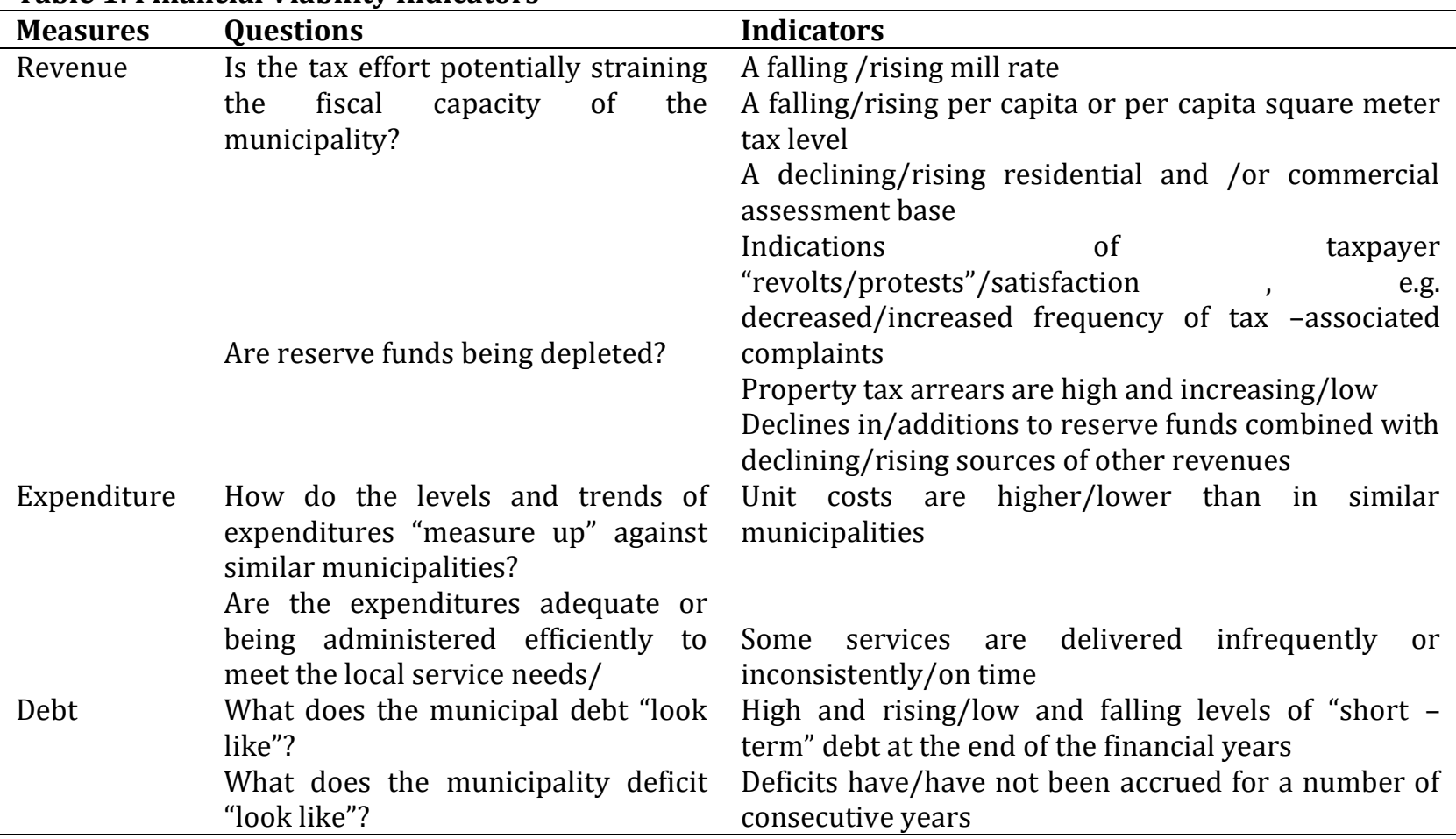

Sources: Adopted from Marshall, J. A. and Douglas, D. J. A. (1997). The Viability of Canadian Municipalities: concepts and Measurements.

As indicated above, the Constitution mandates municipalities to perform local government functions and is expected to provide public services such as municipal roads, street lighting, refuse removal, refuse dumps, and solid waste disposal, local amenities, and municipal parks and recreation, water services and sanitation. . It is therefore imperative to indicate that they are therefore expected to improve the quality of residents' lives at grass-roots level. In order to do that funds are needed to finance the above activities. When one talks about municipal viability reference should be made to the financial status of that municipality. In addition, functioning municipality has a satisfied community, good governance and sound financial system and thus a large part of overall viability must rely on the financial state of a municipality. It goes without saying that, viability should be an ability to produce adequate revenue to pay for its commitments and allow growth while maintaining service levels. 
It therefore stands to reason that local governments need highly skilled capacity thinkers to be able to ensure that their municipalities are viable in terms of identifying, collecting, recording and safeguarding of all revenue. It is so because the municipalities have both a political and an economic purpose. These municipalities also serve an economic purpose by delivering basic services that affect people's everyday lives. Poor financial management and inadequate legal measures to enforce accountability cripple financial nonviability in municipalities. Arguably, councilors have to take politically-motivated and responsible decisions as opposed to irresponsible encounter which can burden municipalities with non-financial viability.

Revenue sources of municipalities: The sources of revenue are the oil of the municipality in everything that they do. Various projects have to be funded and without financial resources these projects will stand to fail. The sources of revenue of the municipalities are property tax rates, service charges, electricity, water, refuse removal, sanitation, and rental of facilities, trading services, membership fees, license fees, and loan funds. According to statistics, municipalities can gain a competitive advantage if they can collect revenue to its fullest capacity. Total potential revenue of selected municipalities per annum was projected as follows: 1999/2000 (R933,600,000), 2000/2001(1,003,100,000) and 2001/2002 (R1,105,900,000).The objective of using the above statistics was to show the sources of revenue that a municipality can generate and also check the trends of total revenue collected for three financial years. The national and provincial governments subsidize municipalities to enable them to provide specific public services.. They are also exempted from paying taxes such as stamp duties, income tax, and tax on donations or gifts received by them. The above mentioned taxes constitute what is termed indirect taxation (Cloete, 1993b). Grants received by the twelve municipalities as subsidies from national government amounted to R103, 111,000. The rationale in using 'this information was to find out whether municipalities receive subsidies or not. Indeed they do receive subsidies to bolster their revenue sources and to bridge the gap between what they can afford and what they cannot afford.

A property tax is a levy or rates on fixed property.. Land and improvements (buildings) can be rated separately. For levying of rates, the land and properties must be valued separately. The usual basis for valuation is the market value, but sometimes the replacement value is used as a basis. The municipality through the use of qualified valuers must undertake the valuation of fixed properties for rating purposes. There are also simplified rating systems that require the owner of the building to pay an amount calculated on the basis of the size of the land (PLANACT, 2001). However, there are number of problems brought about by this system in relation to the transformation and amalgamation of municipalities. There are past decision making on property tax that was influenced by the undemocratic practices of apartheid.

The following is the legacy left by the system: according to (PLANACT, 2001), this state of affair resulted in "Skewed settlement patterns in the geographic and social segregation of residential site and is indicated as follows:- A concentration of wealth and property tax bases, as commercial and industrial activity was located only in former white municipalities, Poor infrastructure and services backlogs under amalgamation, Establishment of non-viable institution such as homelands. The legacy is having a far-reaching effect when trying to create viable, non-racial amalgamation former black local communities.

The following are the side effects:

- Property taxes existed in the urban white areas. The coming together of these municipalities has brought new areas into the property tax net such as R293 and the Black Local Authorities. These tax areas were not paying taxes.

- With the amalgamation of areas, which used to be taxed using valuation dates and systems were put together into a single municipalities. The inconsistencies in the property tax rolls of the amalgamated areas resulted in further inequities, including different effect tax rates among property owners.

- Rural land and properties have not yet been brought into the property tax system or net. The study conducted from the thirteen municipalities shows that rural areas in all instances have not been integrated into the property tax net. The study showed that an estimated 1000000 plus minus people reside in the rural areas who were not in the tax net and as such collecting taxes from the rural areas are concerning for economic viability municipalities point of view (CEPAD and Solace International, 1996). 
Operating budget: it would be unreasonable to discuss revenue sources of municipalities without mentioning the operating budget. In fact there is a link between the sources of revenue of a municipality and the budget amount. It must be a prerogative of the municipality to put a budget plan together based on the revenue sources is having. The consolidated operating budget of these municipalities is as follows: 1999/2000 (R846, 100,000), 2000/2001 (R978, 700,000) and 2001/2002 (R1,115,400,000).

Operating expenditure: Is referred as expenditure by a municipality (Ismail et al, 1997). The objective of discussing the operating expenditure is to show the relationship between the sources of revenue, the budget and the expenditure incurred. Municipalities spend their money generated from their sources of income. They utilize these monies to employ staff, buying of equipment, goods and services, material used to construct and maintain streets, electricity and water and reticulation systems. Cloete (1993b) posits that municipalities are restricted to spend money available to them. In order to spend properly they must have prepared an approved estimate of expenditure. The operating expenditure for the selected municipalities under consideration was 1998/1999 (R722, 000,000), 1999/2000(R923, 780,523), 2000/2001(R959, $320,000)$

Capital expenditure: It can be incurred when the municipality acquires durable assets (Ismail et al, 1997). In order to finance these assets, capital finance is needed. Capital finance is money that is used for expenditure on terms with a useful lifespan of more than one year. The money is mainly used to build infrastructure for delivery of service. The study showed that expenditure on capital projects for the financial years 1998/1999, $1999 / 2000$ and 2000/2001 which needed financial injection amounted to R121,697,000, R137,539,000 and R129,770,000 respectively.

The need for capital finance stems from the fact that much capital expenditure are expensive and require huge capital. Municipalities cannot afford to finance capital projects over a period of one year. The sources of capital loan finance are generated by the municipality itself and for the service such as leasing and user charges. External source are loan finances that are made to municipalities through parastatal development finance (Planact, 2001). The objective of citing capital expenditure in this section is to indicate the influence, which such expenditure may have to the municipal financial viability and autonomy. As s indicated above, the capital expenditure comprises and external and internal sources. This means that if the internal sources are insufficient, that particular municipality has to seek the help of the external sources. Capital expenditure will also interrogate the financial viability of the municipality.

Outstanding debts: the institutional viability and financial adversity of various municipalities is decisive. The Department of Constitutional Affairs in its document titled Municipal Infrastructure Investment Framework (South Africa, Republic, 1999b) states that many municipalities face financial difficulties. It stated that these difficulties emanated from the transitional pressures of the integration municipalities based on new boundaries. Amongst others, municipalities faced with the situations:-previous unsustainable in certain and institutional reorganization. The objective of discussing the amount of monies owed to various municipalities is to show that municipalities are sacrificing lot of revenue. The revenue forgone would be contributing and adding more money to the economy of the municipalities in question. This would however be left to the authorities to add more capacity to revamp the collection of outstanding debts entirely. The study revealed that a total amount owed by residents of the selected municipalities since 1998 to 2001 was 1998/1999(R121,003,183), 1999/2000(R132,716,457) and 2000/2001(R334,328,538) respectively.

Various municipalities in the research are taking certain steps to recover such outstanding revenue through the discontinuing services, handing over of arrear amounts to attorneys for collection, taking actions and summons, effective credit control, utilize debt collections, indigent policy, remind debtors to pay their accounts, legal processes and suspending electricity, community meetings and Provision of quality service, sending of monthly accounts timeously, termination of services, permit residents to apply for extension of payments, facilitators educate non-payers, arrangement for arrear accounts, campaign to enforce payments, the consumers signs for extension of time and in terms of the council resolutions the consumer would not pay interest on overdue accounts, accounts are send out at least 21 days before due date, arrangements with debtors are made before the $15^{\text {th }}$ of the month and campaigns to pay by councilors are made. 
A major initiative aimed at accelerating delivery of basic services and housing, promoting the resumption services charges and bond installments, creating sustainable and efficient local government was, launched by former President Nelson Mandela. However, the culture of non-payment still exists, unfortunately, the communities were not properly educated after the collapse of the apartheid system and it handicaps the development of various municipalities under study. The state of affairs is till serious in the municipalities that are in most cases having deficits and helped by grants or subsidies. This state of affairs is not healthy for the survival of the municipality. However, this matter is left to authorities to investigate and rectify where necessary.

Revenue collection: the objective is to show the potential revenue that can be collected from the rural areas. The objective was also to check whether rural communities can add value in terms of ensuring effective contribution towards the financial viability of municipalities in Limpopo Province. The study also checked the type of revenue collected from the rural areas. It was apparent that the revenue can be exploited form electricity, water services charges and rates. However, only Makhado and Mogalakwena municipalities indicated that they collected R2 million from the rural areas respectively. The above statistics shows that a lot can be done in collecting revenue from the rural areas. There is a lot of potential revenue apparently in the rural areas especially that nurses, teachers and clerks reside in these areas.

Self-sustainability of municipalities: the objective of whether a municipality can survive without grants or subsidy was to determine if subsidies are important for running the municipality. Out of twelve municipalities studied, it was found that eight (8) indicated that they cannot survive without grants and four (4) stated that they could survive without grants. Polokwane, Ba-Phalaborwa, Makhado, Mogalakwena, Thabazimbi, Bela-Bela, Tzaneen and Fetakgomo stated that they could not survive without grants. Lephalale, Molemole, Musina and Modimolle indicated that they would survive without grants. The wisdom is however questionable.

Effect of the financial aid to municipalities: the objective of this statement was to determine whether the financial aid has any bearing on the operations of the municipalities. Four (namely: Ba-Phalaborwa, Makhado, Lephalale and Bela-Bela) out of twelve municipalities cited that the financial aid does not have an effect on the operations of their municipalities. The reasons advanced were: municipalities were independent in taking decisions; National government monitors financial viability of municipalities and ensures that municipalities are accountable to the communities and that they carry out national mandates. However, eight (8) (namely: Musina, Modimolle, Greater Tzaneen, Mogalakwena, Thabazimbi, Polokwane and Fetakgomo) of the municipalities projected that the financial aid is having an effect on the operation of the municipalities. The rationale confirming the state of affairs were that implementation of the indigent grant policy to subsidize poor households are in place, infrastructure development is planned by national and if there no grants allocated and received the increases in tariffs will not be affordable.

Payment of property taxes by provincial and national governments: the objective of this was to ascertain the contribution which is made by the provincial and national governments to enhance revenue for various municipalities. The following municipalities (Polokwane R6 million, Thabazimbi R50, 000, Mogalakwena R2 million, Modimolle R300, 000, Musina R654,000, Molemole R2 million, Ba-Phalaborwa R2m, Makhado R1 million, Bela-Bela R2 million and Lephalale R2 million respectively) indicated that they collect property tax rates from national and provincial spheres of governments. On the flip side Greater Tzaneen and Fetakgomo did not collect property tax rates from national and provincial government. The above state of affairs shows that there is some kind of different policies used in the collection of property taxes from national and provincial governments. A proper and standardized policy would uniformly especially with regards to the collection of revenue from provincial and national governments.

Autonomy of municipalities: When a municipality cannot or does not fulfill an executive obligation as mandated by the Constitution or legislation, the provincial government may intervene. It can do so by taking appropriate steps to ensure fulfillment of that obligation. To this end, Provinces are required to monitor, support, strengthen the capacities terms of Sections, 154(1) and 155(6) of the Constitution. These are overlapping duties by the two spheres of governments. The autonomy of the municipalities is questionable especially when it comes to the capacitating and support given to the municipalities. The state of affairs 
brings in the question as to how can another sphere support the other sphere if that sphere is autonomous? This will be left for further research. Despite the fact that national government actually has the mandate as transfer for basic services and municipal instructions, municipalities is having autonomy as is stipulated. It should be mentioned, the objective of this structure of the question was to ascertain whether municipalities do have autonomy or not. De Villiers (1992) defines autonomy as the ability if a sub-national government to act in self-determination. The autonomy should portray a situation to municipalities that can be conducted and decisions taken without external interference.

The ability of an institution can be influenced by imperatives such as economically and socially e.g. financial resources, management skills, administrative capability and infrastructure restraints. Table 2 illustrate revenue versus expenditure per municipality that will determine whether a municipality is financial autonomous and viable or not. In order to confirm whether municipalities studied are really autonomous the matter was interrogated.

- Eight out twelve municipalities indicated that they are autonomous. The following are municipalities in question: Polokwane, Modimolle, Molemole, Makhado, Bela-Bela, Lephalale and greater Tzaneen.

The above municipalities mentioned the following as reasons of being autonomous: the council has the ability to pass by-laws, approves the budget, takes decisions relating to areas within its jurisdiction, the municipality receives its revenue from the town, the council has elected councilors who take decisions pertaining to the municipalities, municipalities collect own income and they are responsible for their own revenue, Provincial and national governments only monitors their activities of the councils and councils make their own decisions. Table 2 shows the potential revenue collected against the actual expenditure incurred by the municipalities under study during the financial years 1999/2000 to 20000/2001.Potential revenue and expenditure of municipalities:- the potential revenue and expenditure incurred during the fiscal years $1999 / 2000$ and 2000/2001 were compared to verify whether the municipalities in question generated a surplus of savings or deficits and viable or not viable after they have expended for various projects and activities. The autonomy and financial viability had to be emphasized to give effect to the above citations.

The information as tabulated in Table 2 shows that some of the municipalities under study only produced economic profit, other had surpluses and rests had deficits all the way. This state of affairs shows that these municipalities are not financially viable and it would be difficult for them to be self-sustaining without the subsidy from the national and provincial governments.

Table 2: Potential Revenue versus Actual Operating Expenditure-1999/2000 and 2000/2001

\begin{tabular}{|c|c|c|c|c|c|c|c|c|}
\hline $\begin{array}{l}\text { Name of } \\
\text { municipality }\end{array}$ & $\begin{array}{l}\text { Revenue } \\
2000 / 2001 \\
\end{array}$ & $\begin{array}{l}\text { Expenditure } \\
2000 / 2001\end{array}$ & $\begin{array}{l}\text { Deficits/Surplus } \\
2000 / 2001\end{array}$ & $\begin{array}{l}\text { Remarks } \\
2000 / 2001 \\
\end{array}$ & $\begin{array}{l}\text { Revenue } \\
1999 / 2000 \\
\end{array}$ & $\begin{array}{l}\text { Expenditure } \\
1999 / 2000\end{array}$ & $\begin{array}{l}\text { Deficits/Surplus } \\
1999 / 2000\end{array}$ & Remarks \\
\hline Fetakgomo & 0 & 0 & 0 & Not viable & 0 & 0 & 0 & $\begin{array}{l}\text { Not } \\
\text { viable }\end{array}$ \\
\hline Thabazimbi & $26,000,000$ & $30,000,000$ & $-4,000,000$ & Not viable & $24,000,000$ & $28,000,000$ & $-4,000,000$ & $\begin{array}{l}\text { Not } \\
\text { viable }\end{array}$ \\
\hline Bela-Bela & $40,000,000$ & $40,000,000$ & 0 & Viable & $40,000,000$ & $40,000,000$ & 0 & Viable \\
\hline Makhado & $88,000,000$ & $92,000,000$ & $-4,000,000$ & Not viable & $84,000,000$ & $81,000,000$ & $3,000,000$ & $\begin{array}{l}\text { Strongly } \\
\text { viable }\end{array}$ \\
\hline Mogalakwena & $91,000,000$ & $81,000,000$ & $10,000,000$ & $\begin{array}{l}\text { Strongly } \\
\text { viable }\end{array}$ & $74,000,000$ & $73,000,000$ & $1,000,000$ & $\begin{array}{l}\text { Strongly } \\
\text { viable }\end{array}$ \\
\hline Modimolle & $28,500,000$ & $35,900,000$ & $-7,400,000$ & Not viable & $28,400,000$ & $29,700,000$ & $-1,300,000$ & $\begin{array}{l}\text { Not } \\
\text { viable }\end{array}$ \\
\hline $\begin{array}{l}\text { Capricorn } \\
\text { District }\end{array}$ & $75,000,000$ & $29,000,000$ & $46,000,000$ & $\begin{array}{l}\text { Strongly } \\
\text { viable }\end{array}$ & $81,000,000$ & $32,000,000$ & $49,000,000$ & $\begin{array}{l}\text { Strongly } \\
\text { Viable }\end{array}$ \\
\hline Polokwane & $337,600.000$ & $338,800,000$ & $-1,200,000$ & Not viable & $313,200,000$ & $299,400,000$ & $13,800,000$ & $\begin{array}{l}\text { Strongly } \\
\text { viable }\end{array}$ \\
\hline $\begin{array}{l}\text { Greater } \\
\text { Tzaneen }\end{array}$ & $164,000,000$ & $154,000,000$ & $10,000,000$ & $\begin{array}{l}\text { Strongly } \\
\text { viable }\end{array}$ & $155,000,000$ & $129,000,000$ & $26,000,000$ & $\begin{array}{l}\text { Strongly } \\
\text { viable }\end{array}$ \\
\hline Musina & $28,097,823$ & $25,798,755$ & $2,299,068$ & $\begin{array}{l}\text { Strongly } \\
\text { viable }\end{array}$ & $24,738,283$ & $25,734,435$ & $-996,152$ & $\begin{array}{l}\text { Not } \\
\text { Viable }\end{array}$ \\
\hline $\begin{array}{l}\text { Ba- } \\
\text { Phalaborwa }\end{array}$ & $85,000,000$ & $118,000,000$ & $-33,000,000$ & Not viable & $72,000,000$ & $109,000,000$ & $-37,000,000$ & $\begin{array}{l}\text { Not } \\
\text { viable }\end{array}$ \\
\hline Molemole & $2,000,000$ & $6,000,000$ & $-4,000,000$ & Not viable & $2,000,000$ & $6,000,000$ & $-4,000,000$ & $\begin{array}{l}\text { Not } \\
\text { viable }\end{array}$ \\
\hline Total & $1,003,0097,823$ & $903,498,755$ & $-179,699,068$ & & $933,338,282$ & & $98,500,848$ & \\
\hline
\end{tabular}

Sources: Adapted from selected municipalities 
The following municipalities confirmed that they are not autonomous: Thabazimbi, Mogalakwena, Musina and Fetakgomo. These municipalities indicated that the non-autonomous is to them determined by the factors: - the municipalities are dependent on grants from provincial and national governments, the councils prepare budget according to norms of the national treasury, governed by the rules of the national and Limpopo province, Local government Association In Limpopo, the Department of Local Government approves certain matters e.g. Land trust Fund and they are also governed in terms of the national Legislations. However, the population can also determine the municipality tax base in a particular area and that can also ensure the autonomy and financial viability if these municipalities. The twelve studied municipalities recorded total of 2.6 million people residing in their area of jurisdiction.

Autonomy and financial viability: continuous exploitation of sources of revenue for local authorities will ensure the increases of delivery of services in various municipalities. All officials responsible for managing municipal institutions can only achieve the exploitation through the use if proper financial corporate strategies. The campaign to raise more revenue for the municipality must start from the housekeeper up to the executive mayor of all the municipalities. Certainly, these municipalities will be self-sustainable and gain more autonomy in terms of legislation in the true sense of the words. This would be so because their municipalities will be financially viable. It would seem that in the South African scenario, the autonomy and financial viability of local authorities has been a problem for a long time. The following are the municipalities that showed whether they are financially viable: and or not as per the indicated financial years:

Viable status in the year 1999/2000 was Bela-Bela and Musina, 2000/2001 was Bela-Bela.

Strongly viable status: In the financial year 1999/2000 Makhado, Mogalakwena and Polokwane were recorded as such, while in 2000/2001 Mogalakwena and Capricorn district showed favorable figures.

Not viable status: The Municipalities whose figures showed not viable status during the financial year 1999/2000 were: Molemole, Thabazimbi, Modimolle, Lephalale and Phalaborwa. While in 2000/2001 financial year Lephalale, Thabazimbi, Makhado, Molemole, Modimolle, Musina, Polokwane and BaPhalaborwa showed that they were not viable.

Equitable share and tax base: a lot of municipalities in the Limpopo province appear to have no strong tax base. This state of affairs is prevalent in the municipalities such as Fetakgomo, which was investigated. This would be left to the government to provide finances to these municipalities in the form of a strong equitable share, subsidies and other developmental programs to make them self-sustaining in the long-run. The equitable share also offers bridging finances to the municipalities to meet their commitments (South Africa, Republic, 1999d; Hattingh, 1998). In the Limpopo Province the National government has provided all the municipalities with sufficient equitable share to assist them to fund various municipal services.

It was found that, the municipalities under study lack revenue base, there are still a culture of non-payment of services prevailing, and solely survive through the subsidy from national or provincial governments (South Africa, Republic, 1998c). Most of the municipalities have incorporated rural areas which are still outside of the tax net. Their autonomy is as tabulated in the Constitution. They make some decisions regarding their municipal areas and the majority's tentative financial and developmental matters are planned by the provincial and national government. A financial viable municipality is one viable economy and depended on its own revenue or income. In the light of the above discussions, the autonomy and financial viability if municipalities in the Limpopo Province leaves much to be desired and can further be left for further investigations by academic institutions and private sector just to assist government to drastically transform autonomy and financial viability of local authorities.

\section{Conclusion and Recommendations}

The following are the recommendations for this study to aid those involve in the strategic planning in various municipalities, provincial and national spheres of governments:-

Policy alternative: Policy imperative and alternatives with regards to autonomy and financial viability of local authorities in the Limpopo Province is recommended. It is recommended that revenue share from value 
added tax be considered the municipalities in Limpopo. The municipalities in Limpopo can also consider increased revenue by building of factories which can quickly generate sufficient revenue for example: mining sand and gravel. The municipalities can establish bond regiment and use them for financing municipalities' services. Revenue can be exploited and created by holding exhibitions, cinemas, festivals and leveraging on cultural activities is recommended. The municipalities can also leverage on auctioning of municipal properties.

Investment in public infrastructure: Investment in public infrastructure such as water and sewerage treatment facilities, reticulation, streets and highways, and other physical plants, can be repaid, from municipalities - taxes and tariffs and from intergovernmental transfers. Financing these facilities overtime allows a municipality to build more quickly, and to recover the up-front cost from those who benefit. The ability to borrow long term for capital investment goes to the heart of municipalities' service delivery responsibilities. Without the above cited investment, municipalities cannot accelerate the delivery of services and stimulate economic viability, therefore all municipalities should implement Public Investment Infrastructure as an obligatory function to have economic growth that would attracts more viability to municipalities.

\section{Acknowledgements}

I would like to thank the participating municipalities for having afforded me an opportunity to research autonomy and viability in the Limpopo Province. My special thanks go to the MEC for the Department of Local Government and Housing, Mayors, the Head of Department: Department of Local Government and Housing, and Municipal Managers of the municipalities appearing in this study. Mr Makunyane-Mayor of Polokwane I thank you. I would have not put it together if it was not the efforts and commitment of the following officials: Mr Du Plessis P S A Town Treasurer of the Greater Tzaneen Municipality, Mr Rabe, G Assistant Town Treasurer of Ba-Phalaborwa municipality, M/s Mapule M Municipal Manager of the Fetakgomo municipality, Mr Eksteen G the Acting Town Treasurer of Bela-Bela Municipality, Mr Mosam M the Town Treasurer of Modimolle municipality, Mr Hlako H.M the Municipal Manager of Molemole Municipality, Mr Masengane d Deputy Town Treasurer of Makhado Municipality, Mr Voigt W.C Financial Manager of Musina Municipality, Mr Makgoka K J Assistant Town Treasurer of Polokwane Municipality, Mr Bouwer A Town Treasurer of Lephalale Municipality, Mr Du Preez R Town Treasurer Thabazimbi Municipality, Mr Seabela C K Acting Financial Manager Capricorn District Municipality, Mr Joubert W D Acting Town Treasurer of Mogalakwena Municipality, Mr Mphahlele P Financial Officer of the Limpopo Local Government Association and Mr Mike Mabunda the Deputy Director for the Department of Local Government \& Housing (Limpopo).

\section{References}

Catanese, J. and Schineder, J.C. (1979). Urban Planning. New York: McGraw Hill Inc.

CEPAD and Solace International. (1996). The future of Local Government in the rural Areas: An Evaluation and Action Programme for the Northern Province.

Cloete, J. J.N. (1993a). Towns and cities. Their Government and Adminitration 2nd edition. Pretoria: Van Schaik.

Cloete, J. J.N. (1993b). South African Local Government and Adminitration. Pretoria: Van Schaik.

Cloete, J. J.N. (1993c). Central Regional and Local Government and Administration. Pretoria: Van Schaik.

Cloete, F. (1995). Local Government Transformation. Cape Town: Juta.

Cloete, J. J.N. (1997). South Afircan Municipal Government and Administration. Pretoria: Van Schaik.

Craythorne, D. L. (1997). Municipal Administration: A handbook. Fourth Edition. Cape Town: Juta.

De Beer, J and Lourens, L.(1995). Local Government, the Road to Democracy. Johannesburg:-Midrand: EDUCUM.

De Villiers, B. (1992). Regional governmen in the New south Africat. Pretoria: HSRC Publishers.

De Villiers, P. F.A and Meiring, M .H. (1995). The essesence of being a Municipal councillor. Port Elizabeth: University of Port Elizabeth.

Emislie, T.S. (1991). The Regional Levies. Handbook. Durban: Butterworths.

Esman, M.J. (1991). Management Dimensions of Development. Perspectives and Strategies. Austin: Kumarian Press.

Gildenhuys, J. S. (1997a). Introduction to Local Government Finance. Pretoria: Van Schaik. 
Gildenhuys, J. S. (1997b). Restructuring your Local Government. A practical Guide . Pretoria: Van Schaik.

Gaffneys Group.(2001). Gaffney's Local Government in South Africa 2000/2001. Johannesburg: Gaffney group.

Hanekom, et. al. (1987). Key Aspects of Public Administration. Durban: Butterworths.

Hattingh, J. (1998). Government Relations. Pretoria: UNISA.

Ismael, N.et al (1997). Local Government Management. Cape Town: Juta.

Marshall, J.A and Douglas, D.J.A. (1997). The Viability of Canadian Municipalities: concepts and Measurements. Toronto: ICURR Press.

Meiring, M. H and De Villiers, P.F.A. (1994a). Focus on change in the public sector contemporary issues. Port Elizabeth: University of Port Elizabeth.

Meiring, M. H and Parson, C.R. (1994b). Fundamental Public Administration. A Guide for changing South Africa. Port Elizabeth: University of Port Elizabeth.

Humphries, R. (1992). National Party and state perspectives on regionalism. African Insight, 22(1), 52-64.

PLANACT. (2001). Making towns and cities work for people. Braamfontein: PLANACT

South African Local Government Association (SALGA). (2001). Local government and Land Restitution. Official Publication of the South African Local Government Association,1(3), 15 -25.

South Africa, Republic. (1909). The Union of South Africa, South Africa Act, 1909. Pretoria: Government Printers.

South Africa, Republic. (1961a). Republic of South Africa Constitution Act, Act 32 of 1961. Pretoria: Government Printers.

South Africa, Republic. (1961b). Provincial Government Act, Act 32 of 1961. Pretoria: Government Printers.

South Africa, Republic (1962).Proclaimation R293/1962: Regulations for the Administration and control of Twonships in Black Areas in terms of the Black Administration Act 38 of 1927 and the Development trust and Land Act 18 of 1936. Pretoria: Government Printers.

South Africa, Republic (1980). Report of the committee of inquiry into the finances of local authorities in South Africa. Pretoria: Government Printers.

South Africa, Republic (1982a). Report of the Croeser work group concerning the report of the committee of inquiry into the finances of local authorities in South Africa. Pretoria: Government Printers.

South Africa, Republic. (1982b). Black Local Authorities Act, Act 102 of 1982. Pretoria: Government Printers.

South Africa, Republic. (1990). Browne Committee of 1990. Report of the committee of inquiry into the finances of local authorities in South Africa. Pretoria: Government Printers.

South Africa, Republic. (1993). The Local Government Transitional Act (LGTA). Pretoria: Government Printers.

South Africa, Republic. (1996). Republic of South African Constitution Act, Act 108 of 1996. Pretoria: Government Printers.

South Africa, Republic. (1998a). White Paper on Local Governmen 1998.. Pretoria: Government Printers

South Africa, Republic. (1998b). Municipal Structures Act, Act 117 of 1998. Pretoria: Government Printer.

South Africa, Republic. (1998c). Project Viability Report. Pretoria: Government Printers.

South Africa, Republic. (1999a). Green Paper on local Government. Pretoria: Minsitry for Constitutional Development.

South Africa, Republic. (1999b). Municipal Infrastructure Investiment Framework. Pretoria: Government Printers.

South Africa, Republic. (1999c). Annual Report on the equitable share for Local Government 1998/99 Financial Year. Pretoria: Government Printers.

South Africa, Republic. (1999d). Division of Revenue Act, Act 30 of 1999. Pretoria: Government Printers.

South Africa, Republic. (2000). Municipal Systems Act, Act 32 of 2000. Pretoria: Government Printers.

UNISA. (1994). Public Administration. Management of Public and Municipal finances. Pretoria: UNISA.

UNISA. (1999). A reality check for local government authorties in the Limpopo Province: Comparative study. Politeia, 18(2), 19-30. 